\title{
New records of the Paleotropical migrant Hemianax ephippiger in the Caribbean and a review of its status in the Neotropics
}

\author{
Johanna Hedlund (D) a,b*, Eva Ehrnsten ${ }^{\mathrm{c}, \mathrm{d}}$, Christina Hayward ${ }^{\mathrm{e}}$, Philipp Lehmann (1)d and \\ Alex Hayward ${ }^{\mathrm{b}}$ \\ ${ }^{a}$ Department of Biology, Centre for Animal Movement Research (CAnMove), Lund University, Lund, \\ Sweden; ${ }^{b}$ Centre for Ecology and Conservation, University of Exeter, Penryn, UK; ${ }^{c}$ Tvärminne Zoological \\ Station, University of Helsinki, Helsinki, Finland; The Baltic Sea Centre, Stockholm University, Stockholm, \\ Sweden; ${ }^{d}$ Department of Zoology, Stockholm University, Stockholm, Sweden; ${ }^{e}$ Mile End, London, UK
}

(Received 24 April 2020; final version received 22 June 2020)

\begin{abstract}
Tropical America is currently experiencing the establishment of a new apex insect predator, the Paleotropical dragonfly Hemianax ephippiger (Odonata: Aeshnidae). H. ephippiger is migratory and is suggested to have colonised the eastern Neotropics by chance Trans-Atlantic displacement. We report the discovery of H. ephippiger at three new locations in the Caribbean, the islands of Bonaire, Isla de Coche (Venezuela), and Martinique, and we review its reported distribution across the Neotropics. We discuss the establishment of $H$. ephippiger as a new apex insect predator in the Americas, both in terms of ecological implications and the possible provision of ecosystem services. We also provide an additional new species record for Bonaire, Pantala hymenaea (Odonata: Libellulidae).
\end{abstract}

Keywords: Odonata; dragonfly; Bonaire; migration; colonisation; ecosystem services

\section{Introduction}

The ABC Islands of Aruba, Bonaire and Curaçao are situated to the far west of the Leeward Antilles in the Caribbean Sea, 25-80 km north of the Venezuelan coast. The archipelago has a semi-arid to arid climate (Figure 1), with average annual rainfall of approximately $563 \mathrm{~mm}$, most of which falls during the rainy season in November-December (Caribbean Institute for Meteorology \& Hydrology (CIMH), 2014). The composition of the odonate fauna of the ABC islands consists primarily of highly mobile taxa. Of the 23 Anisoptera and Zygoptera species recorded by Paulson, de Haseth, and Debrot (2014) for the archipelago, 13 can be denoted as migratory: Tramea onusta, T. calverti, Pantala hymenaea, P. flavescens, Miathyria marcella, Erythrodiplax umbrata, E. berenice, Erythemis vesiculosa, Brachymesia herbida, Anax junius, A. amazili, Hemianax ephippiger, Ischnura ramburii (Boomsma, 1993; Corbet, 2004; De Marmels et al., 2008; Palacino \& Millán, 2010; Russell, May, Soltesz, \& Fitzpatrick, 1998). A further six species are not mentioned as migratory in the literature, but are closely related to known migrant species:

*Corresponding author. Email: johanna.hedlund@biol.lu.se

(c) 2020 The Author(s). Published by Informa UK Limited, trading as Taylor \& Francis Group

This is an Open Access article distributed under the terms of the Creative Commons Attribution License (http://creativecommons.org/ licenses/by/4.0/), which permits unrestricted use, distribution, and reproduction in any medium, provided the original work is properly cited. 


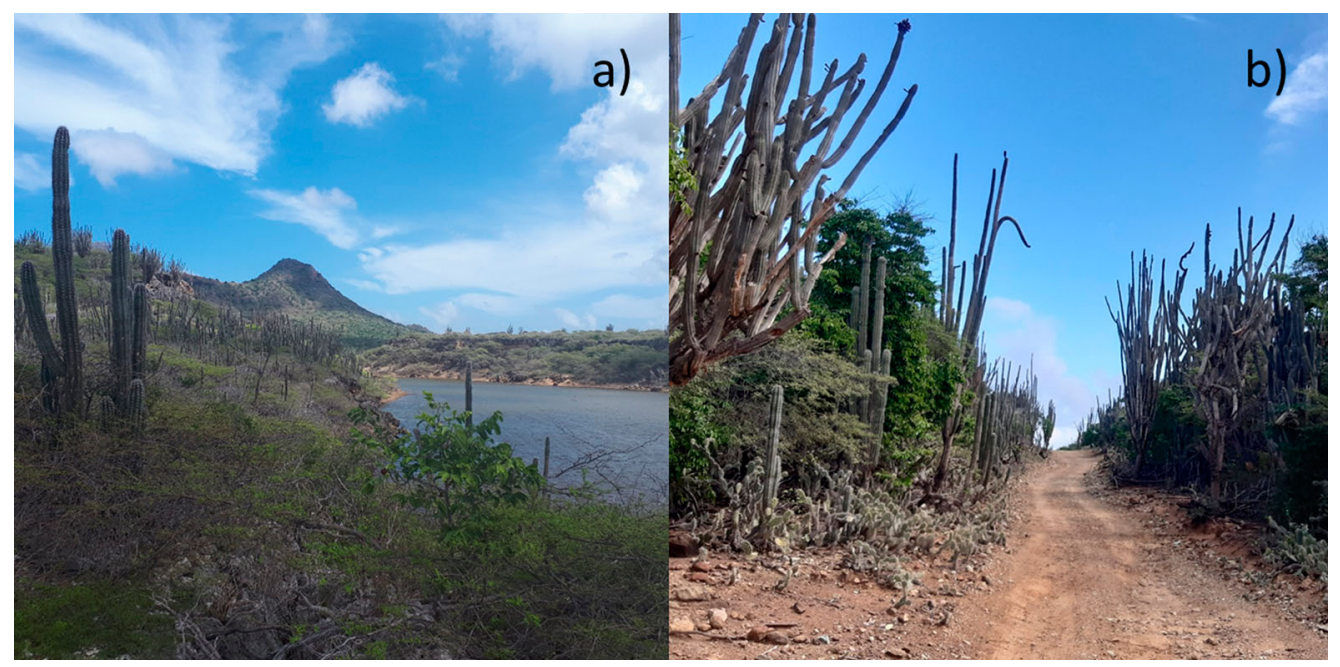

Figure 1. Washington-Slagbaai National Park, (a) general landscape; (b) the location of the observation of the Hemianax ephippiger individual $\left(12^{\circ} 17^{\prime} 04.9^{\prime \prime} \mathrm{N} 68^{\circ} 22^{\prime} 52.1^{\prime \prime} \mathrm{W}\right)$. Photo: Johanna Hedlund and Eva Ehrnsten.

Brachymesia furcata, Erythemis plebeja, Lestes forficula, Orthemis aequilibris, Tramea abdominalis, Tholymis citrina (Paulson, 2002; Kalniņš, 2011). Meanwhile, Micrathyria aequalis is not described as migratory in the literature, but is very common across the Caribbean (Meurgey, 2009) suggesting good dispersal capacity. An additional species, Acanthagrion fluviatile, is quite poorly known, and there is not enough information available to denote its migratory tendencies. Paulson et al. (2014) reported that Curaçao has the highest number of odonate species in the ABC islands, followed by Aruba and lastly Bonaire. However, this observation may be influenced by fieldwork focus, which was centred on Curaçao. Odonates on the ABC islands were considered virtually undocumented until recently, and since the most recent 3-year inventory performed by Paulson et al. (2014), no additional thorough monitoring has been performed.

Here we report observations for two new species for Bonaire, Hemianax ephippiger Selys, 1883 and Pantala hymenaea Say, 1839. Hemianax ephippiger is a species of the Paleotropics, with a primary distribution in Africa, the Mediterranean, Middle-East and South Asia (Dijkstra \& Lewington, 2006; Dumont \& Desmet, 1990). However, over recent years, this highly migrant species has been documented at several locations in the Caribbean, and in French Guyana (Machet \& Duquef, 2004; Paulson et al., 2014). The species' apparent expansion in the region is emphasised by a further two additional observations that we report on, registered on the citizen science platform iNaturalist, yet to be documented in the literature. Pantala hymenaea is also a migrant, and has a wide distribution in North and South America (De Marmels et al., 2008; Paulson, 2018).

\section{Material and methods}

\section{Fieldwork}

Bonaire was visited on 28 November-14 December 2019. During this period most of the island's coastline was visited, including two trips to Washington-Slagbaai National Park (Figure 1). Entomological observations were made ab libitum by all authors and IDs of dragonflies were verified with photographs. 


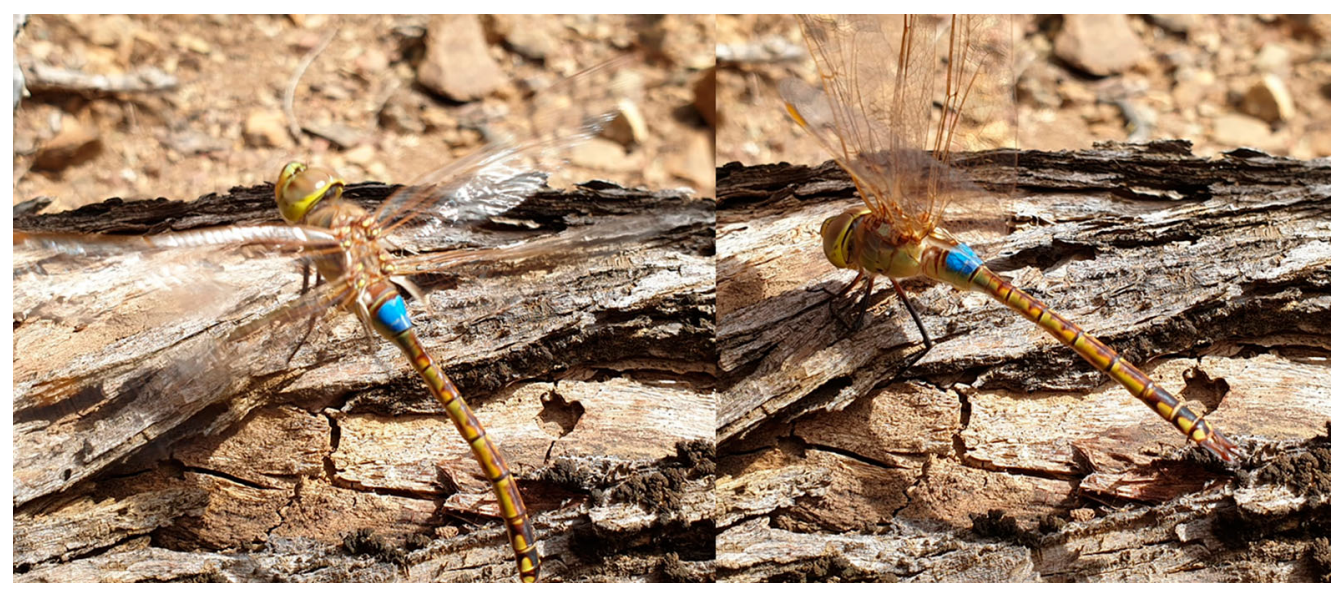

Figure 2. Hemianax ephippiger male, location: Washington-Slagbaai National Park, Bonaire, 2 December 2019. Photo: Alex Hayward.

\section{Literature survey}

A systematic literature search was performed to document records of H. ephippiger's occurrence in the Neotropics. GoogleScholar was queried using combinations of the search terms Hemianax ephippiger, Caribbean, and America. Resultant relevant papers were subsequently used to conduct both forward literature searches in GoogleScholar (i.e. by examining papers that cited the original paper), and reverse literature searches (i.e. by examining the references within a given paper), to identify additional relevant literature. Records were also obtained from the citizen science platform for biodiversity observations, iNaturalist (https://www.inaturalist.org/).

\section{Results}

On 2 December 2019, a large aeshnid dragonfly was observed patrolling around a section of the main road in Washington-Slagbaai National Park (Figure $1,12^{\circ} 17^{\prime} 04.9^{\prime \prime} \mathrm{N} 68^{\circ} 22^{\prime} 52.1^{\prime \prime} \mathrm{W}$ ). A photo of the individual confirmed that the species was Hemianax ephippiger, making this the first observation of the species on the island. The individual was a mature male, with pristine wings and a pronounced blue saddle (Figure 2). One week later, after acquiring permission to capture dragonflies in the park from STINAPA Bonaire National Park Foundation and the WashingtonSlagbaai National Park manager, an attempt was made to relocate and capture the individual, but the effort was unsuccessful. The most commonly observed odonate in the park was Pantala flavescens Fabricius, 1798, which was observed patrolling in groups along roads and close to the coastline. P. flavescens were also observed to be common more generally, across the island. On several occasions (inside Washington-Slagbaai National Park, on the road up to the park and along the west coast) $P$. flavescens was observed in feeding-groups which also contained Pantala hymenaea (Figure 3), another new dragonfly record for the island. The frequency and consistency of observations of $P$. hymenaea is somewhat surprising, since it was not recorded by Paulson et al. (2014) on Bonaire.

In addition to our new record of $H$. ephippiger for Bonaire, two recent records are present on iNaturalist, an online citizen science project website for reporting biodiversity observations (https://www.inaturalist.org/). These two iNaturalist records have not been previously reported in the literature. On 23 November 2019, shortly before our visit to Bonaire, the user 'Silvarojas' uploaded a photograph of a male of $H$. ephippiger, showing pristine wings and a pronounced blue 


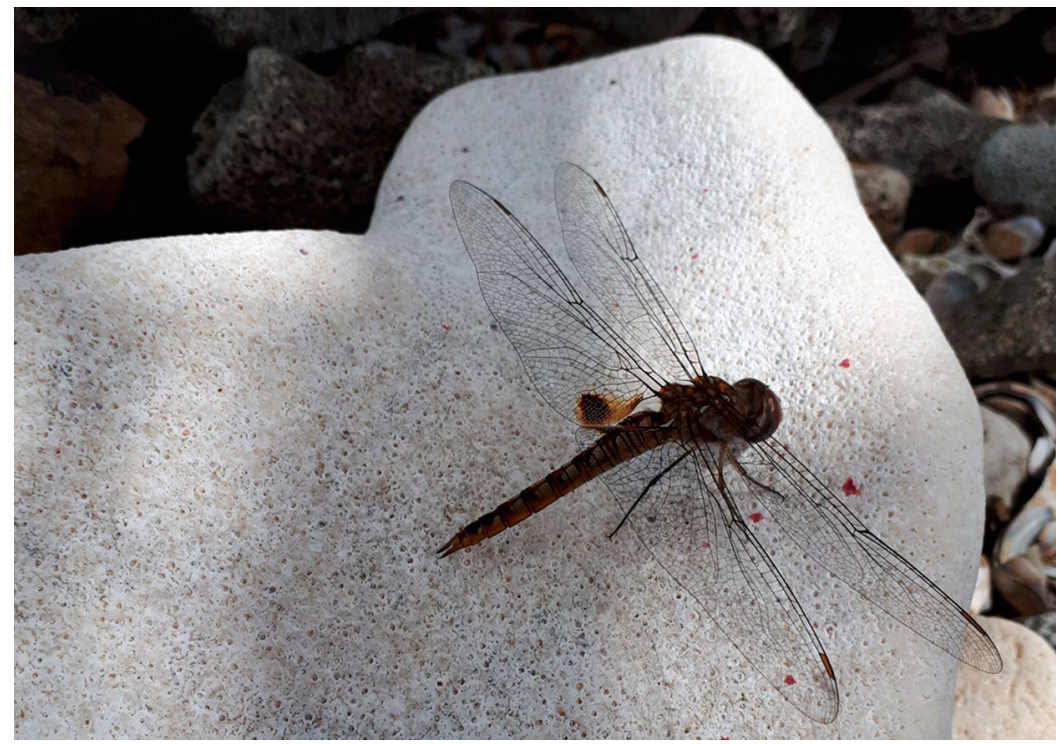

Figure 3. Pantala hymenaea, location: Kaya G.R.E. Herrera, Bonaire, 4 December 2019. Photo: Johanna Hedlund.

saddle. The observation was made on the small island of Isla de Coche, off the coast of Venezuela, about $500 \mathrm{~km}$ east of the $\mathrm{ABC}$ islands (https://www.inaturalist.org/). Observations are assessed in terms of accuracy and reliability on iNaturalist, and this observation has the highest quality grade, categorised as 'research' standard. On 3 March 2020 the user 'Schuetzcxx' documented an additional $H$. ephippiger male for the Caribbean, this time on the island of Martinique, far to the north-east of Bonaire in the Windward Islands. This record was also awarded the quality grade of 'research' on iNaturalist.

All Neotropical observations of $H$. ephippiger reported in the literature (Duquef, 2012; Kalkman \& Monnerat, 2015; Machet \& Duquef, 2004; Meurgey, 2006, 2008a; Meurgey \& Weber, 2007; Meurgey et al., 2012; Paulson et al., 2014; Sibley, 2007) and on iNaturalist (https://www.inaturalist.org/) have been indicated on a map of the region (Figure 4). Two observations of $H$. ephippiger were discarded: (i) Meurgey et al. (2012) include an observation made on the island of Anegada in the British Virgin Islands by Fred Sibley. Sibley has informed the authors that this is a miss-communication, as he has only seen $H$. ephippiger on the island of Guana in The British Virgin Islands (Sibley, pers. comm. via email, 24 March 2020); (ii) Meurgey (2013) mentions an unpublished observation of $H$. ephippiger on Saint-Barthélemy by Karl Questel. Questel suggested the record may be doubtful, and advised against using it (Questel, pers. comm. via email 24 March 2020).

A figure denoting monthly rainfall in the ABC Islands (CIMH, 2014) was plotted against a month of observation of $H$. ephippiger, including the climatically similar island of Isla de Coche (Figure 5). The figure suggests an association between precipitation patterns and presence of adult $H$. ephippiger.

\section{Discussion}

Here we report two new dragonfly species for the Caribbean island of Bonaire, H. ephippiger and $P$. hymenaea. Pantala hymenaea has been recorded in small numbers on Aruba and Curaçao over the last 10 years (Paulson et al., 2014), and is present in most of North, Central and South 


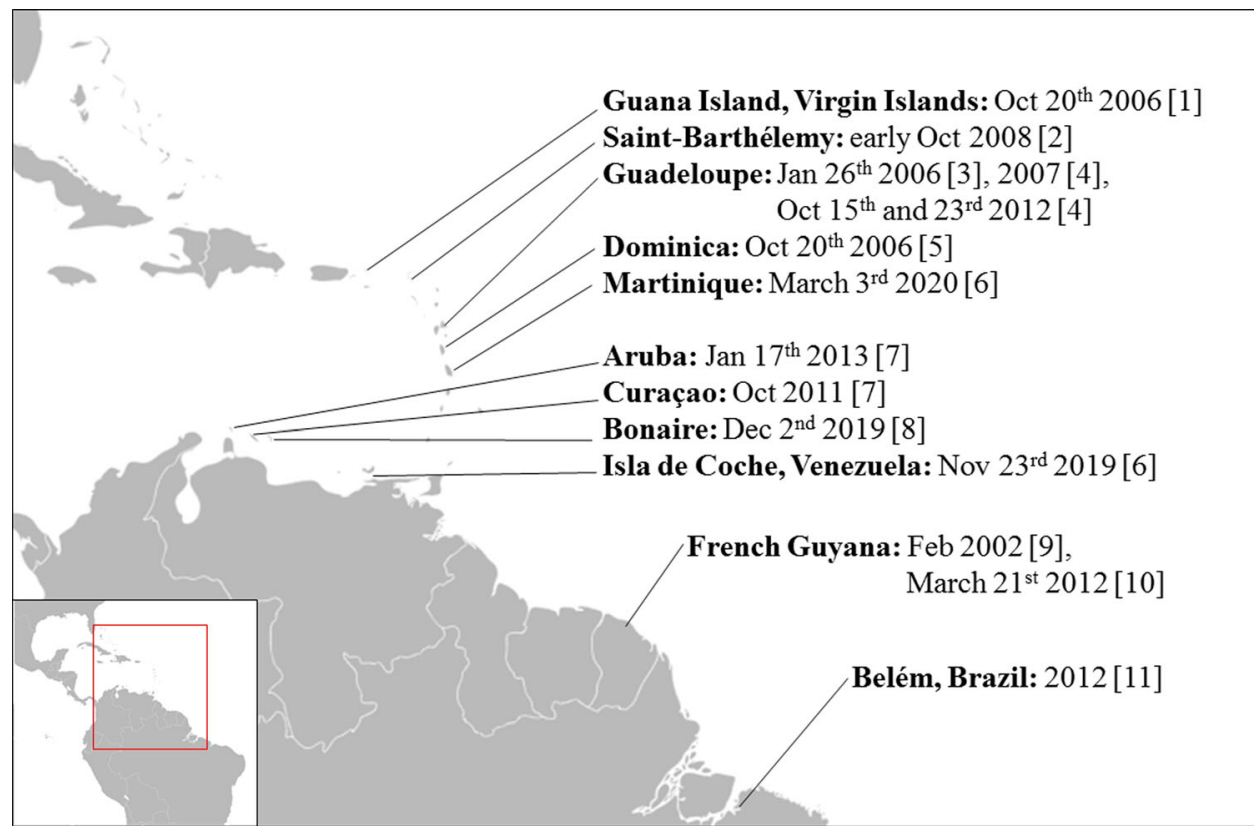

Figure 4. Map indicating reported observations of Hemianax ephippiger in the Neotropics. [1] Sibley (2007); [2] Meurgey (2008a); [3] Meurgey (2006); [4] Meurgey (2013); [5] Meurgey and Weber (2007); [6] iNaturalist; [7] Paulson et al. (2014); [8] this study; [9] Machet and Duquef (2004); [10] Duquef (2012); [11] Kalkman and Monnerat (2015).

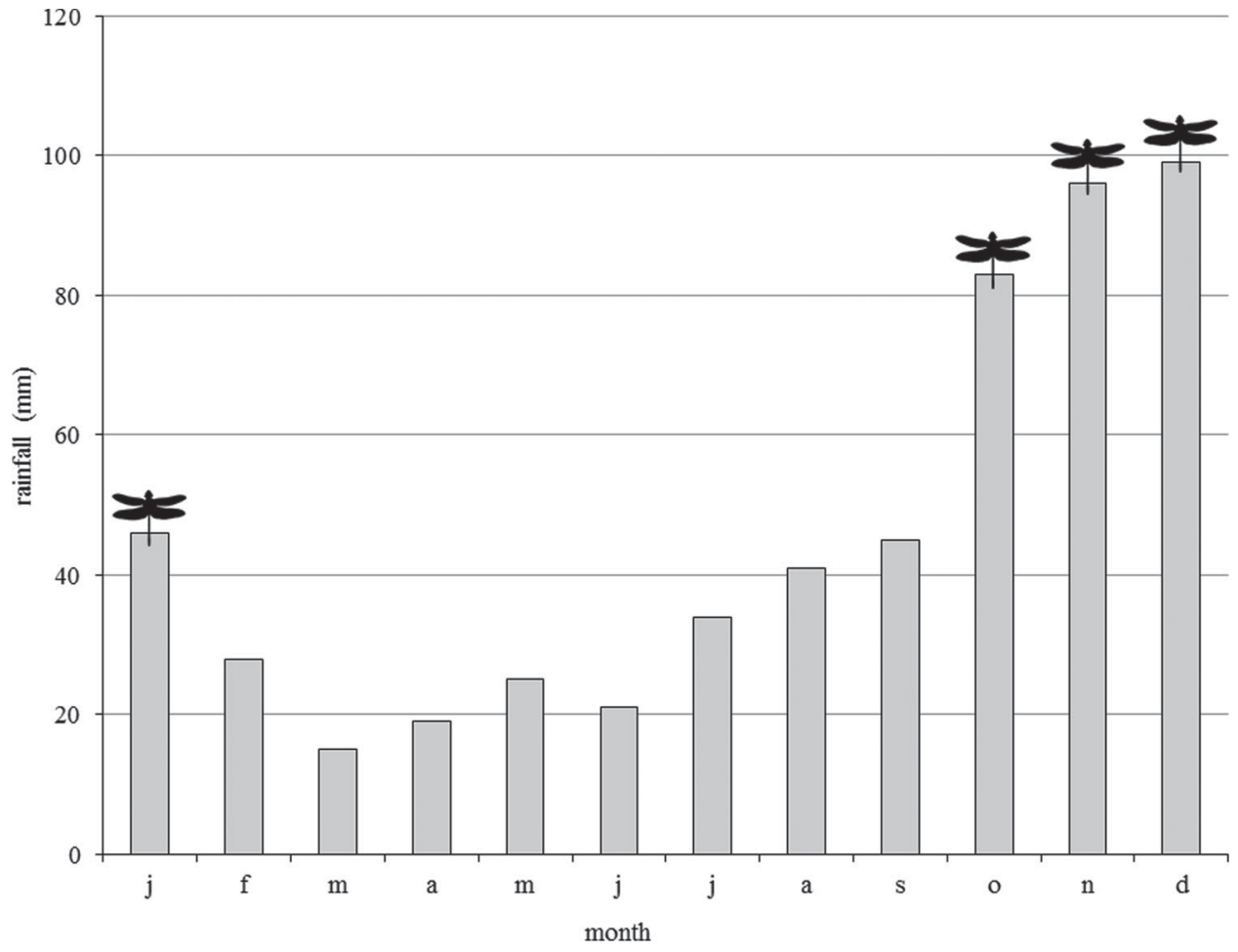

Figure 5. Monthly rainfall in the ABC islands (CIMH 2014). Dragonfly symbols denote months when observations $(\mathrm{N}=4)$ of Hemianax ephippiger have been made on the $\mathrm{ABC}$ islands and Isla de Coche. References for observations are given in Figure 4. 
America (Paulson, 2018). The recent arrival of $H$. ephippiger to the Caribbean from the Paleotropics is an extremely interesting example of long-distance range expansion, the history and ecological implications of which will be extensively discussed below.

\section{Range expansion in the Neotropics}

The first confirmed observation of H. ephippiger in the Americas was in 2002, from French Guyana (Machet \& Duquef, 2004). Since this initial observation, the species has been reported repeatedly in the region (Figure 4). French Guyana is a long distance from what appears to be the core area of observations, i.e. the Lesser Antilles in the Caribbean Sea. Since the first record from the coastal town of Sinnamary in French Guyana, H. ephippiger has been resighted in the vicinity (Duquef, 2012) and also further south, in Brazil (Kalkman \& Monnerat, 2015). However, the number of observations in the Caribbean, and particularly the Lesser Antilles, raises the possibility that this was the original site of colonisation for the species. The apparent establishment of H. ephippiger in the Neotropics (Paulson et al., 2014; Tennessen, 2019), suggests repeated colonisation, or colonisation by a larger group. As persistence after colonisation depends on ecological factors (Havel et al., 2015), such as favourable habitat, low competition, low predation rate, etc., the apparent success of $H$. ephippiger in the Caribbean presumably reflects the suitability of local conditions.

As H. ephippiger has been documented at relatively high latitudes in Europe (Dijkstra \& Lewington, 2006; Ott, 2010), perhaps as a consequence of recent global climate change (Ott, 2010), it may extend its invaded range further, to continental North America in the future (Tennessen, 2019). Indeed, two Neotropical dragonfly species recently established in Florida are speculated to be natural invasions from the Caribbean enabled by climate change (Paulson, 2001). At the same time, the species may also be expected to spread further westwards to Central America, and southwards to South America. However, while H. ephippiger appears to have been relatively successful in expanding its range in the Caribbean, other parts of the Americas may pose a greater challenge, given greater diversity of competitors (Ramírez, Paulson, \& Esquivel, 2000) and predators (Garrigues \& Dean, 2008; Le Bail et al., 2012).

Observations of $H$. ephippiger on the arid $\mathrm{ABC}$ islands and Isla de Coche appear to be seasonally limited to the period that receives the greatest amount of rainfall, i.e. October to January (Figures 4 and 5). Within its core range in the Paleotropics, H. ephippiger avoids woodlands and commonly resides in arid and semi-arid habitats (Corbet, 2004; Dumont \& Desmet, 1990; Silsby, 1993), travelling on rain-bearing weather fronts of the Inter-Tropical Convergence Zone (ITCZ), and reproducing in transient water pools (Corbet, 2004). Consequently, conditions in the arid, seasonal ABC-island region may closely resemble that of the native habitat of the species, and to a greater extent than at other localities where it has been observed within the Americas.

The relative paucity of large insect apex-predators on small and/or isolated islands, such as those in the Caribbean, may constitute an unfulfilled ecological niche, helping to facilitate the establishment of newly arrived species. Indeed $H$. papuensis, a close relative of $H$. ephippiger, has established on New Zealand over the past century, to become one of the dominant odonates (Rowe, Davies, Davies, Pohe, \& Simpson, 2011). Similarly to the ABC Islands, New Zealand has a depauperate odonate diversity, with only 15 resident species (Rowe et al., 2011).

\section{Arrival to the Neotropics}

Hemianax ephippiger is described as an obligate Intertropical Convergence Zone (ITCZ)migrant (Corbet, 2004), and unlike most other dragonfly species, it is known to fly long distances over oceans (Anderson, 2009; Dumont \& Desmet, 1990; Norling, 1967). The seasonal shifts of 
the ITCZ cause changes in wind system direction and precipitation patterns globally, and as such, is a reliable climatic phenomenon used by many insect migrants (Corbet, 2004). In Africa, $H$. ephippiger is thought to emerge from waterbodies supplied by seasonal rains in late autumn, and is often observed migrating in large numbers along the west-African coastline during JanuaryMarch, reaching Europe in early spring (Dumont, 1977; Dumont \& Desmet, 1990). From April to October, north-easterly trade winds, produced by shifts of the ITCZ, carry Saharan dust and aerosol westward over the Atlantic Ocean (Carlson \& Prospero, 1972; Schütz, 1980), constituting possible long-distance vectors of aerial insects (Lorenz, 2009). Thus, trans-Atlantic displacement of $H$. ephippiger, for example during their seasonal migration northward from Africa to Europe, is a likely explanation for their presence in the Neotropics (De Marmels, 2007). However, it is evident that some H. ephippiger recorded in the Americas must have emerged in the region, since several specimens are described as tenerals (recently emerged adults), or as being fresh looking with pristine wings, both of which rule out a long and strenuous flight over the Atlantic Ocean (Duquef, 2012; Meurgey, 2006; Sibley, 2007). Supporting this hypothesis is the discovery of $H$. ephippiger exuviae on Aruba and Curaçao (Paulson et al., 2014; Tennessen, 2019), proving that the dragonfly is reproducing on the islands. Consequently, it is clear that H. ephippiger is now resident in the Americas, and that observations of it in the region are not simply sightings of individuals repeatedly invading from across the Atlantic.

Meurgey (2006) concluded that H. ephippiger individuals observed in Guadeloupe in 2006, and in French Guyana in 2002 (Machet \& Duquef, 2004), which all appeared 'young but mature', had arrived from Africa using north-easterly trade winds. However, new African arrivals and locally bred individuals cannot be definitively separated without verification, for example via stable isotopic analysis (e.g. as done for Anax junius by Hallworth, Marra, McFarland, Zahendra, \& Studds, 2018). Thus, stable isotope analysis of $H$. ephippiger specimens collected across the Neotropics will be an interesting topic for future research, to better clarify patterns of dispersal versus local reproduction.

In 1988, swarms of Paleotropical Schistocerca gregaria (desert locusts) arrived in South America and the Caribbean (Rosenberg \& Burt, 1999). Phylogenetic analyses of locust mitochondrial DNA suggest that such events occurred many times historically, and that these dispersals gave rise to all Neotropical Schistocerca spp. (Lovejoy et al., 2006). Meanwhile, another dragonfly species of African origin that migrates along the West African coast (Dumont, 1977), Tramea basilaris, has also been reported in Cuba, the Lesser Antilles and South America on several occasions (Belle, 1988; Meurgey, 2008a, 2012). Thus, chance arrival and windborne displacements to the Americas of migratory, African insects has occurred several times historically, and may have substantial evolutionary and ecological potential.

\section{Ecological implications in the Neotropics}

The consequences of the arrival and establishment of a new, insect apex-predator such as $H$. ephippiger in the Caribbean are unclear. In general, concerns connected to the arrival of new odonate species are scarce in the literature (Winterbourn \& Pohe, 2013), and are typically mild when raised (Marinov, Richards, \& Theuerkauf, 2013). The ability of migrants to translocate in order to utilise spatiotemporal redistribution of seasonal resources has enabled certain insect species to expand their ranges and reach large population sizes (Chapman, Reynolds, \& Wilson, 2015). Within several generations, migratory Anax spp. can exploit several ecosystems across a whole continent (May, Gregoire, Gregoire, Lubertazzi, \& Matthews, 2017). Accordingly, it is plausible that $H$. ephippiger remains highly mobile within its new Neotropical range, moving between habitats as they become seasonally suitable in terms of breeding sites and resources. It has been noted that dragonflies can have substantial effects both as predators and competitors 
when invading a new locale by disrupting local food webs (Winterbourn \& Pohe, 2013; Woodward \& Hildrew, 2002a). Dragonfly nymphs are also voracious predators, consuming up to $14 \%$ of their body weight per day (Woodward \& Hildrew, 2002b), and adults are highly successful hunters, capturing prey in $97 \%$ of attacks (Olberg, Worthington, \& Venator, 2000). Effects of larvae-larvae predation, by larger anisopterans on smaller zygopterans, can also be instrumental in shaping zygopteran species composition, and field transplant experiments have shown that mortality rates of zygopteran larvae are higher when exposed to a novel anisopteran predator (McPeek, 1990). Adult H. ephippiger are known to prey on smaller dragonflies, including the common resident species $P$. flavescens (Pierce, 2017), and within its native range, H. ephippiger often migrate in enormous swarms (Dumont \& Desmet, 1990), indicating the species' ability to mass-emerge and aggregate. Consequently, the ecological potential of H. ephippiger's arrival to the Neotropics could be considerable.

Dispersal and range expansion of migratory insects, such as the rapid spread of Spodoptera frugiperda, the fall army worm (Ma et al., 2019) or Anopheles stephensi, a malaria-carrying mosquito (Surendran et al., 2019), are often regarded as a threat to human food security and health, and also to ecosystem function (Lehmann et al., 2020; Tu et al., 2020). However, negative consequences are not a certainty. Indeed, arrival and establishment of new dragonfly species to a region can potentially constitute an ecosystem service.

Recent, reoccurring outbreaks of mosquito-borne diseases such as chikungunya (Johansson, Powers, Pesik, Cohen, \& Erin Staples, 2014), zika (Dowd et al., 2016), and dengue are an alarming trend in the Americas and in the Caribbean (Jury, 2008; Kumar, Gittens-St Hilaire, \& Nielsen, 2018; Messina et al., 2014). The ABC islands have a history of outbreaks of all three diseases (Leão et al., 2017; Huits et al., 2018; WHO, 2000), which are spread by the mosquito species Aedes aegypti and A. albopictus. Dragonfly nymphs are important predators of malaria-carrying mosquito larvae (Roux \& Robert, 2019), and aeshnids are particularly effective predators of mosquitos in arid climates (Stav, Blaustein, \& Margalit, 2005), and biocontrol agents of Aedes larvae (Akram \& Ali-Khan, 2016; Samanmali et al., 2018). Meanwhile, adult dragonflies are known to feed on large numbers of adult mosquitos (May, 2019; Yuval \& Bouskila, 1993). As increased predator richness in water habitats has a negative effect on mosquito richness and density (Carver, Spafford, Storey, \& Weinstein, 2010), the arrival of additional dragonfly species may be an added benefit to mosquito control locally. Furthermore, H. ephippiger nymphs have been shown to successfully control populations of snails that are the secondary host of the Schistosoma nematode, which is the cause of schistosomiasis, one of the most socioeconomically devastating parasitic diseases in the world (WHO, 2020; Younes, El-Sherif, Gawish, \& Mahmoud, 2015).

\section{Conclusion}

The majority of dragonflies present on the ABC islands are migratory, suggesting that high mobility is a key characteristic for the local odonate fauna. H. ephippiger, a long-distance migrant, has become a resident on the islands and is clearly established in the Neotropics. The islands of the Caribbean appear particularly suitable for the species, and observations in the arid regions are associated with rainfall, suggesting that on these locations the species may have adopted a similar seasonality as in the Paleotropics. The arrival of a new insect apex predator such as H. ephippiger may have considerable ecological potential and is the setting of a natural experiment in progress.

\section{Acknowledgements}

The authors thank Caren Eckrich, STINAPA Bonaire National Park Foundation, the Washington-Slagbaai National Park and Albert Crestian for their valuable time and support of our study. 


\section{ORCID}

Johanna Hedlund (D) http://orcid.org/0000-0001-5826-9588

Philipp Lehmann (D) http://orcid.org/0000-0001-8344-6830

\section{References}

Akram, W., \& Ali-Khan, H. A. (2016). Odonate nymphs: Generalist predators and their potential in the management of dengue mosquito, Aedes aegypti (Diptera: Culicidae). Journal of Arthropod-Borne Diseases, 10(2), 253-258.

Anderson, R. C. (2009). Do dragonflies migrate across the western Indian Ocean? Journal of Tropical Ecology, 25(4), 347-358. https://doi.org/10.1017/S0266467409006087

Belle, J. (1988). A record of the old world species Tramea basilaris burmeisteri Kirby from Suriname (Odonata: Libellulidae). Zoologische Mededelingen, 62(1), 1-3.

Boomsma, T. (1993). Dragonflies and damselflies of the Shipstern Nature Reserve (Odonata). Occasional Papers of The Belize Natural History Society, 2(6), 54-58.

Carlson, T. N., \& Prospero, J. M. (1972). The large-scale movement of Saharan air outbreaks over the Northern Equatorial Atlantic. Journal of Applied Meteorology, 11, 283-297. https://doi.org/10.1175/1520-0450(1972)011 < 0283:TLS $\mathrm{MOS}>2.0 . \mathrm{CO} ; 2$

Carver, S., Spafford, H., Storey, A., \& Weinstein, P. (2010). The roles of predators, competitors, and secondary salinization in structuring mosquito (Diptera: Culicidae) assemblages in ephemeral water bodies of the wheatbelt of Western Australia. Environmental Entomology, 39(3), 798-810. https://doi.org/10.1603/en09235

Chapman, J. W., Reynolds, D. R., \& Wilson, K. (2015). Long-range seasonal migration in insects: mechanisms, evolutionary drivers and ecological consequences. Ecology Letters, 18, 287-302. https://doi.org/10.1111/ele.12407

Caribbean Institute for Meteorology \& Hydrology (CIMH). (2014). Caribbean climatology archive. http://rcc.cimh. edu.bb/caribbean-climatology/stations/

Corbet, P. S. (2004). Dragonflies, behaviour and ecology of Odonata (rev. ed.). Colchester: Harley Books.

De Marmels, J. (2007). How and when did the Vagrant Emperor, Hemianax ephippiger (Burmeister, 1839) arrive in the Caribbean? Argia, 19(2), 16.

De Marmels, J., José, C. A., \& Sharpe, C. (2008). Mass migration of the spot-winged glider (Pantala hymenaea) in Venezuela. Argia, 20(2), 6.

Dijkstra, K.-D. B., \& Lewington, R. (2006). Field guide to the dragonflies of Britain and Europe. Gillingham: British Wildlife Publishing.

Dowd, K. A., Ko, S. Y., Morabito, K. M., Yang, E. S., Pelc, R. S., DeMaso, C. R., \& Graham, B. S. (2016). Rapid development of a DNA vaccine for Zika virus. Science, 354(6309), 237-240. https://doi.org/10.1126/science.aai9137

Dumont, H. J. (1977). On migrations of Hemianax ephippiger (Burmeister) and Tramea basilaris (P. de Beauvois) in West and North-West Africa in the winter of 1975/1976 (Anisoptera: Aeshnidae, Libellulidae). Odonatologica, 6(1), 13-17.

Dumont, H. J., \& Desmet, K. (1990). Trans-Sahara and trans-Mediterranean migratory activity of Hemianax ephippiger (Burmeister) in 1988 and 1989 (Anisoptera: Aeshnidae). Odonatologica, 19(2), 181-186.

Duquef, M. (2012). Reproduction probable d'Hemianax ephippiger (Burmeister, 1839) en Guyane (Odonata, Anisoptera: Aeshnidae). Martinia, 28(2), 126.

Garrigues, R., \& Dean, R. (2008). The birds of Costa Rica: a field guide. Ithaca, NY: Zona Tropical Publication, Comstock Publishing Associates. https://doi.org/10.1086/586967

Hallworth, M. T., Marra, P. P., McFarland, K. P., Zahendra, S., \& Studds, C. E. (2018). Tracking dragons: Stable isotopes reveal the annual cycle of a long-distance migratory insect. Biology Letters, 14(12), 20180741. https://doi.org/10.1098/rsbl.2018.0741

Havel, J. E., Kovalenko, K. E., Thomaz, S. M., Amalfitano, S., \& Kats, L. B. (2015). Aquatic invasive species: challenges for the future. Hydrobiologia, 750, 147-170. https://doi.org/10.1007/s10750-014-2166-0

Huits, R., De Kort, J., Van Den Berg, R., Chong, L., Tsoumanis, A., Eggermont, K., Bartholomeeusen, K., Ariën, K. K., Jacobs, J., Van Esbroeck, M., Bottieau, E., \& Cnops, L. (2018). Chikungunya virus infection in Aruba: Diagnosis, clinical features and predictors of post-chikungunya chronic polyarthralgia. PLoS ONE, 13(4), e0196630. https://doi.org/10.1371/journal.pone.0196630

Johansson, M. A., Powers, A. M., Pesik, N., Cohen, N. J., \& Erin Staples, J. (2014). Nowcasting the spread of Chikungunya Virus in the Americas. PLoS ONE, 9(8), e104915. https://doi.org/10.1371/journal.pone.0104915

Jury, M. R. (2008). Climate influence on dengue epidemics in Puerto Rico. International Journal of Environmental Health Research, 18(5), 323-334. https://doi.org/10.1080/09603120701849836

Kalkman, V. J., \& Monnerat, C. (2015). Anax ephippiger (Burmeister, 1839). In J. Boudot \& V. J. Kalkman (Eds.), Atlas of the European Dragonflies and Damselflies (pp. 169-171). Zeist: KNNV Publishing.

Kalniņš, M. (2011). The distribution of southern dragonfly (Odonata) species in Latvia and adjacent territories. Environmental and Experimental Biology, 9(September), 43-52.

Kumar, A., Gittens-St Hilaire, M., \& Nielsen, A. L. (2018). Long-term epidemiological dynamics of dengue in Barbados-one of the English-speaking Caribbean countries. Epidemiology and Infection, 146(8), 1048-1055. https://doi.org/10.1017/S0950268818000900 
Le Bail, P. Y., Covain, R., Jégu, M., Fisch-Muller, S., Vigouroux, R., \& Keith, P. (2012). Updated checklist of the freshwater and estuarine fishes of French Guiana. Cybium, 36(1), 293-319. https://doi.org/10.26028/cybium/2012-361-016

Leão, J. C., Gueiros, L. A., Lodi, G., Robinson, N. A., \& Scully, C. (2017). Zika virus: Oral healthcare implications. Oral Diseases, 23(1), 12-17. https://doi.org/10.1111/odi.12512

Lehmann, P., Ammunét, T., Barton, M., Battisti, A., Eigenbrode, S. D., Jepsen, J. U., \& Björkman, C. (2020). Complex responses of global insect pests to climate warming. Frontiers in Ecologyand the Environment, 18(3), 141-150. https://doi.org/10.1002/fee.2160

Lorenz, M. W. (2009). Migration and trans-Atlantic flight of locusts. Quaternary International, 196(1-2), 4-12. https://doi.org/10.1016/j.quaint.2007.09.038

Lovejoy, N. R., Mullen, S. P., Sword, G. A., Chapman, R. F., \& Harrison, R. G. (2006). Ancient trans-Atlantic flight explains locust biogeography: Molecular phylogenetics of Schistocerca. Proceedings of the Royal Society B: Biological Sciences, 273(1588), 767-774. https://doi.org/10.1098/rspb.2005.3381

Ma, J., Wang, Y. P., Wu, M. F., Gao, B. Y., Liu, J., Lee, G. S., \& Hu, G. (2019). High risk of the fall armyworm invading Japan and the Korean Peninsula via overseas migration. Journal of Applied Entomology, 143(9), 911-920. https://doi.org/10.1111/jen.12679

Machet, P., \& Duquef, M. (2004). Un visiteur inattendu et de taille! .. Hemianax ephippiger (Burmeister 1839) capturé à la Guyane française. Martinia, 20(3), 121-124.

Marinov, M., Richards, S., \& Theuerkauf, J. (2013). Chapter 5. Damselflies and Dragonflies (Insecta: Odonata) of the Mt. Panié and Roches de la Ouaième region, New Caledonia. In F. M. Tron, R. Franquet, T. H. Larsen, \& J.-J. Cassan (Eds.), A rapid biological assessment of the Mt. Panié and Roches de la Ouaième region, province Nord, New Caledonia (pp. 113-130). Berlin: Walter de Gruyter GmbH \& Co. KG. https://doi.org/10.1515/9783110289039.176

May, M. L. (2019). Odonata: Who they are and what they have done for us lately: Classification and ecosystem services of Dragonflies. Insects, 10(3), 62. https://doi.org/10.3390/insects10030062

May, M. L., Gregoire, J. A., Gregoire, S. M., Lubertazzi, M. A., \& Matthews, J. H. (2017). Emergence phenology, uncertainty, and the evolution of migratory behavior in Anax junius (Odonata: Aeshnidae). PLoS ONE 12(9), e0183508. https://doi.org/10.1371/journal.pone.0183508

McPeek, M. A. (1990). Determination of species composition in the Enallagma damselfly assemblages of permanent lakes. Ecology, 71(1), 83-98.

Messina, J. P., Brady, O. J., Scott, T. W., Zou, C., Pigott, D. M., Duda, K. A., \& Hay, S. I. (2014). Global spread of dengue virus types: Mapping the 70 year history. Trends in Microbiology, 22(3), $138-146$. https://doi.org/10.1016/j.tim.2013.12.011

Meurgey, F. (2006). Anax ephippiger (Burmeister, 1839), a new species for the West Indies. Argia, 18(1), 21-22.

Meurgey, F. (2008a). Another case of westward dispersal of African Odonates to the West Indies: Tramea basilaris Palisot de Beauvois Found in Martinique (FWI). Argia, 20(4), 20-21.

Meurgey, F. (2008b). Migration of Pantala hymenaea (spot-winged glider) in the French West Indies. Argia, 20 (4), 12.

Meurgey, F. (2009). The Odonata of Grenada (Lesser Antilles) (Survey report May 1-14). Nantes: Société d'Histoire Naturelle L'Herminier, Muséum d'Histoire Naturelle.

Meurgey, F. (2012). A new case of westward dispersal of an Afrotropical species to the West Indies: keyhole glider Tramea basilaris (Palisot, 1805) in Cuba (Greater Antilles). Argia, 24(4), 26-27.

Meurgey, F. (2013). A catalogue of the West Indian dragonflies (Insecta: Odonata). Annales de La Societe Entomologique de France, 49(3), 298-334. https://doi.org/10.1080/00379271.2013.848066

Meurgey, F., David, G., Picard, L., Poiron, C., \& Questel, K. (2012). Liste Rouge provisoire des Odonates des Antilles françaises et liste des espèces à suivi prioritaire. Nantes: Société d'Histoire Naturelle L'Herminier, Muséum d'Histoire Naturelle.

Meurgey, F., \& Weber, G. (2007). The Odonata of Dominica, British West Indies — 2006 Collecting Trip. Argia, 18(4), $14-16$.

Norling, U. (1967). Hemianax ephippiger (Burm.) found in Iceland (Odonata). Opuscula Entomologica, 32, 99-100.

Olberg, R. M., Worthington, A. H., \& Venator, K. R. (2000). Prey pursuit and interception in dragonflies. Journal of Comparative Physiology- A Sensory, Neural, and Behavioral Physiology, 186, $155-162$. https://doi.org/10.1007/s003590050015

Ott, J. (2010). Dragonflies and climatic change - recent trends in Germany and Europe. BioRisk, 5, $253-286$. https://doi.org/10.3897/biorisk.5.857

Palacino, R., F., \& Millán, C. A. (2010). First records of possible migratory dragonflies in Colombia. Argia, 22(3), 9-10.

Paulson, D. R. (2001). Recent Odonata records from southern Florida - effects of global warming? International Journal of Odonatology, 4(1), 57-69. https://doi.org/10.1080/13887890.2001.9748159

Paulson, D. R. (2002). Odonata records from Nayarit and Sinaloa, Mexico, with comments on natural history and biogeography. Odonatologica, 31(4), 359-370.

Paulson, D. R. (2018). The IUCN Red List of Threatened Species 2018: e.T49254542A65836149. Species factsheet: Pantala hymenaea. http://doi.org/10.2305/IUCN.UK.2018-\%0A1.RLTS.T49254542A65836149.en

Paulson, D. R., de Haseth, C., \& Debrot, A. O. (2014). Odonata of Curaçao, southern Caribbean, with an update to the fauna of the ABC islands. International Journal of Odonatology, 17(4), 237-249. https://doi.org/10.1080/13887890.2014.981877

Pierce, A. J. (2017). The first record of Anax ephippiger for Thailand and Southeast Asia (Odonata: Aeshnidae). Notulae odonatologicae, 8(9), 365-368.

Ramírez, A., Paulson, D. R., \& Esquivel, C. (2000). Odonata of Costa Rica: Diversity and checklist of species. Revista de Biologia Tropical, 48(1), 247-254. 
Rosenberg, J., \& Burt, P. J. A. (1999). Windborne displacements of Desert Locusts from Africa to the Caribbean and South America. Aerobiologia, 15(3), 167-175. https://doi.org/10.1023/A:1007529617032

Roux, O., \& Robert, V. (2019). Larval predation in malaria vectors and its potential implication in malaria transmission: An overlooked ecosystem service? Parasites and Vectors, 12(1), 1-11. https://doi.org/10.1186/s13071-019-3479-7

Rowe, R. J., Davies, C., Davies, D., Pohe, S. R., \& Simpson, E. H. (2011). Tramea loewii (Odonata: Libellulidae), a dragonfly newly arrived in New Zealand. New Zealand Journal of Zoology, 38(2), 189-193. https://doi.org/10.1080/03014223.2011.558516

Russell, R. W., May, M. L., Soltesz, K. L., \& Fitzpatrick, J. W. (1998). Massive swarm migrations of dragonflies (Odonata) in eastern North America. The American Midland Naturalist, 140(2), $325-342$. https://doi.org/10.1674/0003-0031(1998)140[0325:msmodo]2.0.co;2

Samanmali, C., Udayanga, L., Ranathunge, T., Perera, S. J., Hapugoda, M., \& Weliwitiya, C. (2018). Larvicidal potential of five selected dragonfly nymphs in Sri Lanka over Aedes aegypti (Linnaeus) larvae under laboratory settings. BioMed Research International, 2018, 8759459. https://doi.org/10.1155/2018/8759459

Schütz, L. (1980). Long range transport of desert dust with special emphasis on the Sahara. Annals of the New York Academy of Sciences, 338(1), 515-532. https://doi.org/10.1111/j.1749-6632.1980.tb17144.x

Sibley, F. (2007). Second record of Anax ephippiger (Vagrant Emperor) from the West Indies. Argia, $18(4), 17$.

Silsby, J. (1993). A review of Hemianax ephippiger, the Vagrant Emperor. Journal British Dragonfly Society, 9(2), 47-50.

Stav, G., Blaustein, L., \& Margalit, Y. (2005). Individual and interactive effects of a predator and controphic species on mosquito populations. Ecological Applications, 15(2), 587-598.

Surendran, S. N., Sivabalakrishnan, K., Sivasingham, A., Jayadas, T. T. P., Karvannan, K., Santhirasegaram, S., \& Ramasamy, R. (2019). Anthropogenic factors driving recent range expansion of the Malaria vector Anopheles stephensi. Frontiers in Public Health, 7(MAR), 1-11. https://doi.org/10.3389/fpubh.2019.00053

Tennessen, K. J. (2019). Aeshnidae. In K. J. Tennessen (Ed.), Dragonfly nymphs of North America (pp. 73-159). Cham: Springer.

Tu, X., Hu, G., Fu, X., Zhang, Y., Ma, J., Wang, Y., \& Chapman, J. W. (2020). Mass windborne migrations extend the range of the migratory locust in East China. Agricultural and Forest Entomology, 22(1), 41-49. https://doi.org/10.1111/afe.12359

Winterbourn, M. J., \& Pohe S. R. (2013). Life histories of four dragonfly species (Odonata: Anisoptera) in northern New Zealand. New Zealand Entomologist, 36(1), 8-14. https://doi.org/10.1080/00779962.2012.752225

Woodward, G., \& Hildrew, A. G. (2002a). Body-size determinants of niche overlap and intraguild predation within a complex food web. Journal of Animal Ecology, 71(6), 1063-1074. https://doi.org/10.1046/j.1365-2656.2002.00669.x

Woodward, G., \& Hildrew, A. G. (2002b). Differential vulnerability of prey to an invading top predator: Integrating field surveys and laboratory experiments. Ecological Entomology, 27(6), 732-744. https://doi.org/10.1046/j.1365-2311. 2002.00462.x

World Health Organization (WHO). (2000). WHO Report on Global Surveillance of Epidemic-prone Infectious Diseases World. Vol. WHO/CDS/CS (Issue 3).

World Health Organisation (WHO). (2020). Fact sheet: Schistosomiasis. https://www.who.int/news-room/fact-sheets/ detail/schistosomiasis

Younes, A., El-Sherif, H., Gawish, F., \& Mahmoud, M. (2015). Potential of Hemianax ephippiger (OdonataAeshnidae) nymph as predator of Fasciola intermediate host, Lymnaea natalensis. Asian Pacific Journal of Tropical Biomedicine, 5(8), 671-675. https://doi.org/10.1016/j.apjtb.2015.04.008

Yuval, B., \& Bouskila, A. (1993). Temporal dynamics of mating and predation in mosquito swarms. Oecologia, 95(1), 65-69. https://doi.org/10.1007/BF00649508 